\title{
PRADINIŲ KLASIŲ MOKYTOJŲ IR VISUOMENĖS SVEIKATOS SPECIALISTU BENDRADARBIAVIMO POREIKIS
}

\author{
Indrè Budrevičiūtė ${ }^{2}$, Faustas Stepukonis ${ }^{1}$ \\ ${ }^{1}$ Klaipèdos universiteto Sveikatos mokslu fakultetas, ${ }^{2}$ Klaipèdos visuomenès sveikatos biuras
}

Raktažodžiai: pradinių klasių mokytojai, visuomenès sveikatos specialistai, bendradarbiavimas.

\section{Santrauka}

Tyrimo tikslas - išanalizuoti pradinių klasių mokytojų ir visuomenès sveikatos specialistų bendradarbiavimo poreikị.

Metodai. Kiekybiniame tyrime, kuris atliktas naudojant apklausą raštu ir ištisinès atrankos metodą, dalyvavo 162 Radviliškio ir Šiaulių mokyklų pradinių klasių mokytojai. Apklausa vykdyta $2018 \mathrm{~m}$. balandžio bei $2019 \mathrm{~m}$. spalio-lapkričio mènesiais.

Rezultatai ir išvados. Dauguma Radviliškio (72,7 proc.) ir Šiaulių (59,7 proc.) pradinių klasių mokytojų visiškai sutinka su teiginiu, kad mokykloje sveikatos priežiūra vaidina svarbų vaidmenį. Didžioji dalis Šiaulių (55,8 proc.) bei Radviliškio (48,5 proc.) pradinių klasių mokytojų mano, kad sveikatos ugdymo veiklai mokykloje yra skiriamas pakankamas dèmesys. Trumpesni darbo stažą turintys mokytojai dažniau pritarè minčiai, kad blogi vaikų tarpusavio santykiai bei prasti santykiai su tèvais ir auklètojais veikia vaikų sveikatą $(\mathrm{p}<0,01)$. Nustatyta, kad net

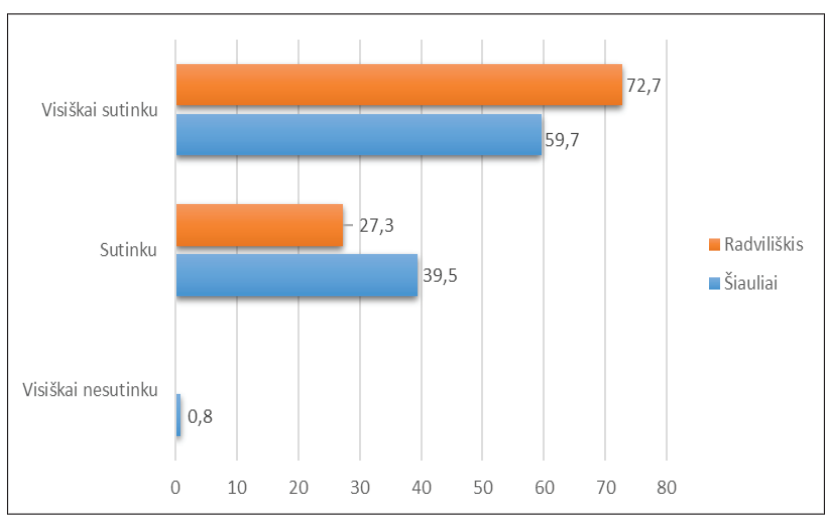

1 pav. Mokytojų sutikimas su teiginiu, kad sveikatos priežiūra mokykloje yra svarbi (proc.).
83 proc. iš visų apklaustų respondentų visiškai sutinka, kad mokykloje yra reikalingas visuomenès sveikatos specialistas. Daugiau nei du trečdaliai - 71 proc. apklaustujų - nurode, kad jiems teko bendradarbiauti su visuomenès sveikatos specialistu.

\section{Ivadas}

Bendradarbiavimas tarp pradinių klasių mokytojų ir visuomenès sveikatos specialistų yra aktuali šiandieninès visuomenès tema. Vaikų sveikatos ugdyme, jos stiprinimo bei gerinimo procesuose turi dalyvauti ne vien pradinių klasių mokytojai, bet ir visuomenès sveikatos specialistai - kuo stipresnis ryšys bus tarp jų, tuo lengviau bus pasiekiami užsibrèžti tikslai. Mokykla turi užtikrinti sveiką fizinę ir socialinę aplinką, propaguoti sveikatingumą, skirti pakankamai dèmesio vaikams ịsisavinant žinias apie sveikatą ir tobulinant sveikos gyvensenos įgūdžius, bendradarbiauti ne tik su šeima, bet ir su visuomenès sveikatos specialistu bei visa bendruomene moksleivių sveikatos priežiūros klausimais. Mokykloje dirbantys visuomenès sveikatos priežiūros specialistai, savo ruožtu, turi dirbti ne tik su vaikais, bet ir su jų tèvais bei mokytojais.

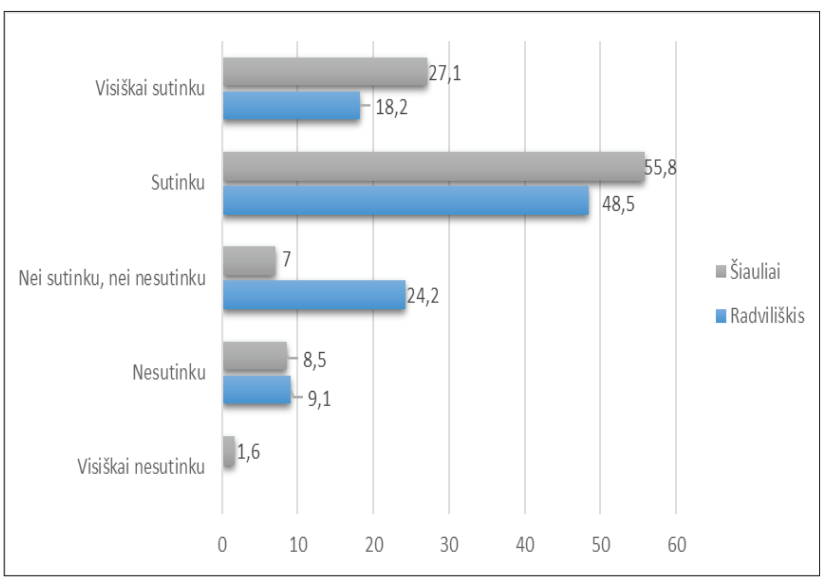

2 pav. Mokytojų sutikimas su teiginiu, kad dėmesys, skiriamas sveikatos ugdymo veiklai mokyklose, yra pakankamas (proc.). 
Siekiant, kad sveikatos ugdymas mokyklose būtų sèkmingas ir efektyvus, svarbu, jog mokytojai bei visuomenès sveikatos priežiūros specialistai turètų reikiamų žinių ir suprastų, kaip tą sveikatą ugdyti. Mokytojai turi mokèti pritaikyti tinkamas sveikatos ugdymo programas pradiniu klasių mokiniams. Vienas iš svarbiausių visuomenès sveikatos specialistų tikslų yra suprantamai perteikti informaciją apie sveikatą mokytojams, vaikams, jų tėvams ir visai visuomenei. Visuomenès sveikatos specialistai, bendradarbiaudami su mokytojais, turi mokyti vaikus sveikos gyvensenos, įskiepydami kiekvienam mokiniui supratimą, kad sveikata yra brangiausias žmogaus turtas ir reikia ja rūpintis.

Tyrimo tikslas - išanalizuoti pradinių klasių mokytojų ir visuomenès sveikatos specialistų bendradarbiavimo galimybes.

\section{Tyrimo medžiaga ir metodai}

Tyrimas vyko 2018 m. balandžio mènesị trijose Radviliškio mokyklose ir 2019 m. spalio-lapkričio mènesiais dešimtyje Šiaulių mokyklų, davusių sutikimą atlikti apklausą. Tyrimas atliktas, pasirinkus apklausą raštu, klausimyną sudaré 17 uždarujų klausimų. Respondentai ị pateiktus klausimus galèjo atsakyti, pasirinkdami jiems priimtiniausią atsakymą. Visų Radviliškio ir Šiaulių pradinių klasių mokytojų skaičius - 227 mokytojai. Pasitelkus imties dydžio skaičiuoklę ir nustačius galimą 5 proc. paklaidą, buvo apskaičiuota, kad reikalingas imties dydis yra 143, o atliekant ištisinę atranką, apklausti 162 pradinių klasių mokytojai. Taigi imties dydis yra pakankamas, kad būtų gauti statistiškai reikšmingi rezultatai. Dalyvavimo dažnis sudare 88,3 proc. Statistine duomenų analizė atlikta, naudojant SPSS programą. Spirmano (Spearman) koreliacijos testas naudotas nustatyti ranginių

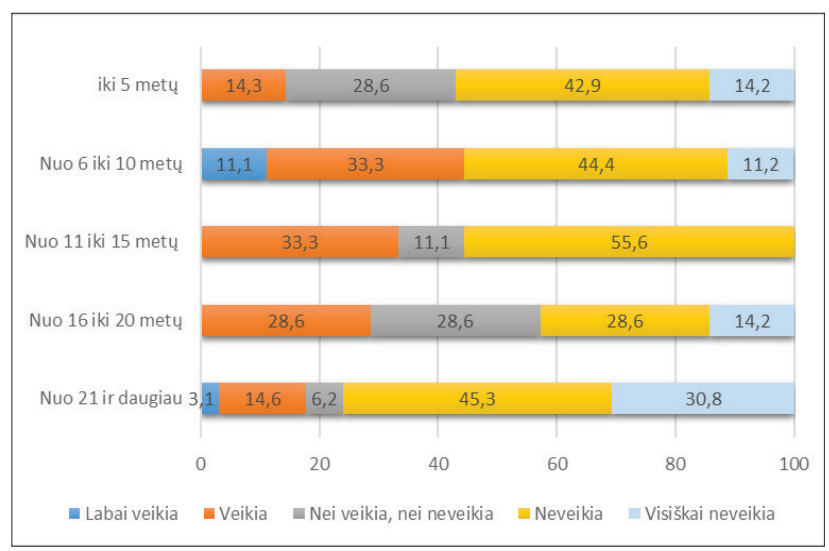

3 pav. Mokytojų požiūris (atsižvelgiant ị jų pedagoginio darbo stažą) ị tai, kaip stipriai veikia vaikų sveikatą / neveikia vaikų sveikatos blogi vaikų tarpusavio santykiai (proc.). kintamujų statistines sąsajas, o $\chi^{2}$ testas padèjo nustatyti nominalinių kintamujų statistines sąsajas. Rezultatų skirtumai laikyti statistiškai reikšmingais, kai $\mathrm{p}<0,05$.

\section{Tyrimo rezultatai}

Tyrimas atskleidè, kad dauguma Radviliškio (72,7 proc.) ir Šiaulių (59,7 proc.) pradinių klasių mokytojų visiškai sutinka su teiginiu, kad sveikatos priežiūra mokykloje yra svarbi (1 pav.).

Didžioji dalis Šiaulių (55,8 proc.) ir Radviliškio (48,5 proc.) pradinių klasių mokytojų pritaria minčiai, kad dèmesys, skiriamas sveikatos ugdymo veiklai mokykloje, yra pakankamas (2 pav.).

Trumpesni darbo stažą turintys mokytojai statistiškai reikšmingai $(p<0,01)$ dažniau pritare teiginiui, kad blogi vaikų tarpusavio santykiai veikia vaikų sveikatą ( 3 pav.).

Be to, trumpesnị darbo stažą, igytą, einant pedagogo pareigas, turintys mokytojai dažniau $(\mathrm{p}<0,05)$ pritare požiūriui, kad vaikų sveikatą veikia blogi santykiai su tėvais ir auklètojais (4 pav.).

Mokytojų pageidaujamos bendradarbiavimo su visuomenès sveikatos specialistais sritys pateikiamos 1 lentelejje. Mokytojai labiausiai linkę bendradarbiauti dèl vaikų sveikatos problemų ( 73,5 proc.), profilaktinių patikrinimų ( 66,7 proc.) ir sveikatos ugdymo renginių organizavimo (40,7 proc.). Tik 22,8 proc. mokytojų nurode, kad yra linkę bendradarbiauti su visuomenès sveikatos specialistais dèl savo pačių sveikatos.

Atsižvelgus ị mokytojų darbo stažą, nustatyta, kad ilgesni darbo stažą turintys respondentai dažniau $(\mathrm{p}<0,05)$ pritaré bendradarbiavimui dèl vaikų sveikatos problemų (5 pav.).

Atsižvelgiant ị mokytojų amžių, nustatyta, kad vyresnio

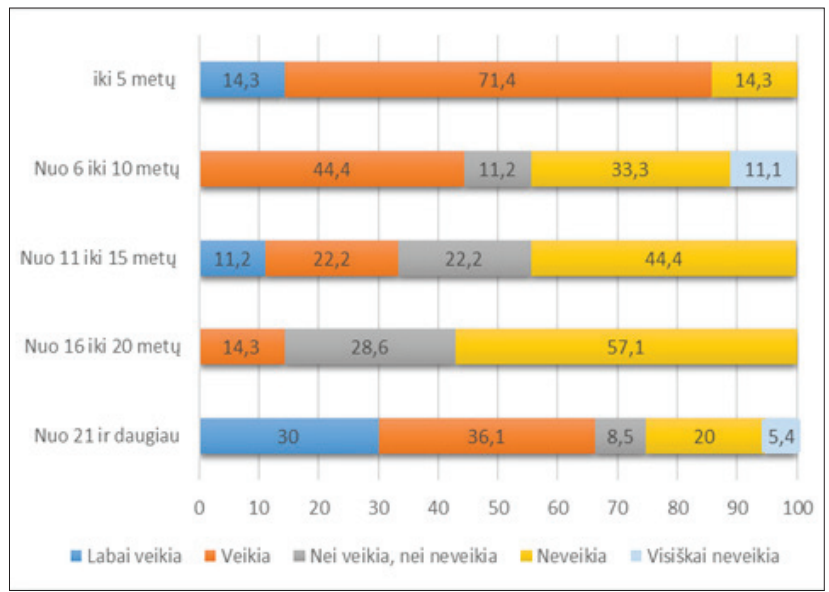

4 pav. Mokytojų požiūris (atsižvelgiant jų pedagoginio darbo stažą) ị tai, kaip stipriai veikia vaikų sveikatą / neveikia vaikų sveikatos blogi santykiai su tèvais ir aukletojais (proc.). 
1 lentelè. Mokytojų bendradarbiavimo su visuomenès sveikatos specialistais tikslinès sritys.

\begin{tabular}{|c|c|c|c|c|c|c|c|c|}
\hline & $\begin{array}{l}\text { Visiškai } \\
\text { sutnku }\end{array}$ & Sutinku & $\begin{array}{l}\text { Nei sutinku, } \\
\text { nei nesutinku }\end{array}$ & Nesutinku & $\begin{array}{c}\text { Visiškai } \\
\text { nesutinku }\end{array}$ & $\begin{array}{c}\text { p reikšmè } \\
\text { atsižvelgiant i stažąa }\end{array}$ & $\begin{array}{c}\text { p reikšmè atsižvelgiant } \\
\text { ¡ kvalifikaciją }\end{array}$ & $\begin{array}{c}\text { p reikšmé } \\
\text { atsižvelgiant i a mžiu }\end{array}$ \\
\hline \begin{tabular}{|l|} 
Dèl vaiku \\
sveikatos
\end{tabular} & $73,5 \%$ & $25,3 \%$ & $0,6 \%$ & $0,6 \%$ & $0 \%$ & $p<0,05$ & $p>0,05$ & $p<0,05$ \\
\hline $\begin{array}{l}\text { Dèl profilaktinių } \\
\text { patikrinimy }\end{array}$ & $66,7 \%$ & $31,5 \%$ & $1,2 \%$ & $0,6 \%$ & $0 \%$ & $p>0,05$ & $p>0,05$ & $p>0,05$ \\
\hline $\begin{array}{l}\text { Dèl sveikatos } \\
\text { ugdymo renginio } \\
\text { organizavimo }\end{array}$ & $40,7 \%$ & $49,4 \%$ & $3,1 \%$ & $4,9 \%$ & $1,9 \%$ & $p>0,05$ & $p>0,05$ & $p>0,05$ \\
\hline \begin{tabular}{|l|} 
Dèl metodinès \\
medžiagos \\
sveikatos ugdymo \\
klausimais \\
\end{tabular} & $32,7 \%$ & $44,4 \%$ & $8,1 \%$ & $11,1 \%$ & $3,7 \%$ & $p>0,05$ & $p>0,05$ & $p>0,05$ \\
\hline \begin{tabular}{|l|} 
Dèl ugdymo \\
aplinkos gerinimo
\end{tabular} & $31,8 \%$ & $43,9 \%$ & $14,9 \%$ & $9,4 \%$ & $0 \%$ & $p>0,05$ & $p>0,05$ & $p>0,05$ \\
\hline Dèl savo sveikatos & $22,8 \%$ & $28,4 \%$ & $22,8 \%$ & $20,4 \%$ & $5,6 \%$ & $p>0,05$ & $p>0,05$ & $p>0,05$ \\
\hline \begin{tabular}{|l} 
Bendradarbiauti \\
neteko
\end{tabular} & $2,5 \%$ & $2,5 \%$ & $1,2 \%$ & $22,8 \%$ & $71 \%$ & $p>0,05$ & $p>0,05$ & $p>0,05$ \\
\hline
\end{tabular}

amžiaus mokytojai dažniau ( $\mathrm{p}<0,05)$,visiškai sutinka“ ar „sutinka“" su teiginiu, jog jie bendradarbiauja su visuomenès sveikatos specialistais dèl vaikų sveikatos problemų (6 pav.).

\section{Rezultatų aptarimas}

Atliktas tyrimas atskleidè daugumos Radviliškio ir Šiaulių mokytojų pritarimą visuomenès sveikatos specialisto pareigybei mokykloje, 83 proc. iš visų apklaustų respondentų visiškai sutinka su teiginiu, kad visuomenès sveikatos specialistas mokykloje yra reikalingas. Kiti autoriai po savo Lietuvoje atliktų tyrimų gavo panašius rezultatus. V. Vetrenkienè, $2011 \mathrm{~m}$. atlikusi kokybinị tyrimą, nustatè, kad bendrojo lavinimo mokyklose dirbantys visuomenès sveikatos priežiūros specialistai yra naudingi ir reikalingi [1]. Be to, V. Vetrenkienè išsiaiškino, kad pernelyg trumpas

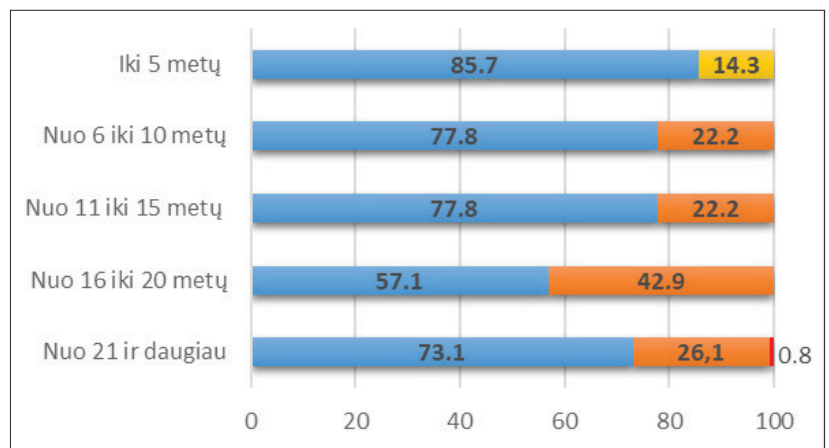

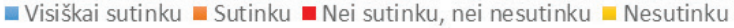

5 pav. Mokytojų poreikis, atsižvelgiant ị jų darbo stažą, bendradarbiauti su visuomenès sveikatos specialistais dèl vaikų sveikatos problemų (proc.). specialisto darbo laikas mokykloje trukdo iki galo atlikti visuomenès sveikatos specialistui jo pareigas [1], o šiame straipsnyje aprašyto tyrimo rezultatai (aukščiau esančiame tekste nepateikti) atskleidè, kad 36,4 proc. respondentų visiškai sutinka, kad deramai atlikti savo darbą visuomenès sveikatos specialistui trukdo netinkamas darbo krūvis, specialistui įstaigoje turint tik dalị etato. R. Proškuvienè ir bendraautoriai 2013 m. atliko tyrimą, atskleidusi mokytojų, dirbančių Vilniaus apskrities bendrojo ugdymo mokyklose, nuomonę, kad vaikų ugdymo aplinką 90 proc. lemia mokinių tarpusavio santykiai [2]. Šio straipsnio autorių tyrimas taip pat išaiškino, kad blogi vaikų tarpusavio santykiai statistiškai reikšmingai veikia vaikų sveikatą. N. Strazdienè ir E. Adaškevičienè, 2009 m. atlikusios tyrimą, nustatè, kad dauguma pradinių klasių mokytojų, stiprindami moksleivių sveikatą, bendradarbiauja su mokykloje dirbančiu visuomenès sveika-

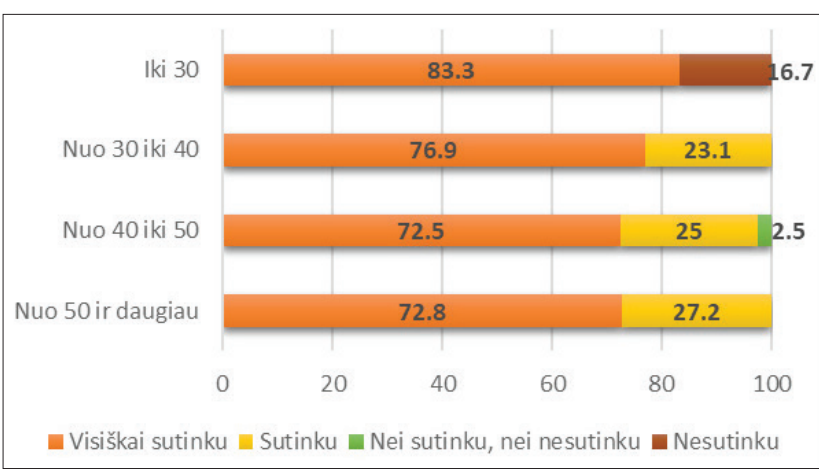

6 pav. Mokytojų poreikis, atsižvelgiant ị jų amžių, bendradarbiauti su visuomenès sveikatos specialistais dèl vaikų sveikatos problemų (proc.). 
tos specialistu (77,5 proc.), tačiau apie penktadalis pedagogų teigè to nedarantys $(22,5$ proc.) [3]. Šio straipsnio autoriu tyrimas patvirtino, kad dauguma pradinių klasių mokytoju dèl vaikų sveikatos problemų linkę bendradarbiauti su visuomenès sveikatos specialistais.

Užsienio šalyse taip pat atlikta keletas tyrimų, analizuojančių panašias problemas. Galima paminèti Kuponiyi ir bendraautorių $2016 \mathrm{~m}$. mokyklose atliktą tyrimą, kuriame dalyvavę 47,8 proc. valstybinių bei 61,6 proc. privačių mokyklų mokytojų nurodè, kad jų mokykloje nedirba visuomenès sveikatos specialistas [4]. Šio straipsnio autoriu tyrimas atskleidè (aukščiau esančiame tekste nepateikta), kad Radviliškio ir Šiaulių mokyklose neatsirado nė vieno mokytojo, kuris pažymètų tai, jog jo / jos mokykloje nedirba visuomenès sveikatos specialistas.

\section{Išvados}

1. Dauguma Radviliškio (72,7 proc.) ir Šiaulių $(59,7$ proc.) pradinių klasių mokytojų visiškai sutinka su teiginiu, kad sveikatos priežiūra mokykloje yra svarbi sritis. Didžioji dalis Šiaulių (55,8 proc.) bei Radviliškio ( 48,5 proc.) pradinių klasių mokytojų pritaria minčiai, kad sveikatos ugdymo veiklai mokykloje skiriamas pakankamas demesys.

2. Trumpesnị darbo stažą turintys mokytojai statistiškai reikšmingai dažniau pritare teiginiui, kad blogi vaikų tarpusavio santykiai bei prasti santykiai su tèvais ir auklètojais veikia vaikų sveikatą.

3. Mokytojai su visuomenès sveikatos specialistais labiausiai linkę bendradarbiauti dèl vaikų sveikatos problemų, profilaktinių sveikatos patikrinimų ir sveikatos ugdymo renginių organizavimo, tačiau retai siekia bendradarbiauti dèl savo pačių sveikatos.

\section{Literatūra}

1. Vetrenkienė V. Visuomenès sveikatos priežiūros specialistų būtinas reikalingumas Kauno bendrojo lavinimo mokyklose. Jaunujjų mokslininkų darbai, Kaunas. 2011;2(31) [žiūrèta 2018 m. gruodžio 19 d.]. Prieiga per internetą: http://vddb. library.lt/fedora/get/LT-eLABa-0001:J.04 2011 ISSN_16488776.N_2_31.PG_80-88/DS.002.0.01.ARTIC.

2. Proškuvienè R., Ustilaitė S., Bulkaitė L. Vilniaus apskrities mokytojų požiūris ị ugdymosi aplinkos veiksnius ir sveikatinimo veiklą. Visuomenès sveikata, Vilnius (Higienos insti- tutas). 2013;2(61) [žiūrèta 2018 m. gruodžio 20 d.]. Prieiga per internetą: http://www.hi.lt/uploads/pdf/visuomenes\%20 sveikata/2013.2(61)/VS\%202013\%202(61)\%20ORIG\%20 S\%20Vilniaus\%20apskrities\%20mokytojai.pdf.

3. Strazdienė N., Adaškevičienė E. Mokytojų pilietinè pozicija ir dalykinè kompetencija ugdant vaikų sveikatą. Tiltai, Klaipèda. 2011;3 [žiūrèta 2019 m. kovo 21 d.]. Prieiga per internetą: http://etalpykla.lituanistikadb.lt/fedora/objects/LT-LDB0001:J.04 2011 1367176285040/datastreams/DS.002.0.01. ARTIC/content.

4. Kuponiyi TO, Amoran EO, Kuponiyi TO. School health services and its practice among public and private primary schools in Western Nigeria. BMC Research Notes, 2016;9:203 [žiūrèta 2018 m. lapkričio 25 d.]. Prieiga per internetą: https://www. ncbi.nlm.nih.gov/pmc/articles/PMC4822242/.

https://doi.org/10.1186/s13104-016-2006-6

\section{NEED FOR COOPERATION BETWEEN PRIMARY SCHOOL TEACHERS AND PUBLIC HEALTH SPECIALISTS}

\section{Budrevičiūtė, F. Stepukonis}

Keywords: primary school teachers, public health specialists, cooperation.

\section{Summary}

The study aims to analyze the need for collaboration between primary school teachers and public health specialists.

Methods. In the quantitative study, written questionnaire and continuous sampling method were used, 162 primary school teachers from Radviliškis and Šiauliai schools have participated. The survey was conducted in April 2018 and October-November 2019.

Results and conclusions. Most primary school teachers from Radviliškis (72.7\%) and Šiauliai (59.7\%) fully agree with the importance of health care at school. The majority of primary school teachers in Šiauliai (55.8\%) and Radviliškis (48.5\%) agree that the attention devoted to health education activities at school is sufficient. Teachers with shorter work experience were more likely to agree that bad relationships among children as well as negative children's relationships with their parents and teachers affect children's health $(p<0.01)$. It was found that $83 \%$ of all respondents totally agree with the need for a public health specialist at school. More than two thirds, i.e. $71 \%$ of respondents indicated that they had cooperated with a public health specialist.

Correspondence to: indre.budreviciute@gmail.com

Gauta 2019-09-20 